\title{
Effect of STEM-based Learning on the Cognitive Skills Improvement
}

\author{
Anugrah Ramadhan Firdaus ${ }^{\bowtie 1}$ \& Galih Dani Septian Rahayu² \\ 1,2 Primary School Teacher Education Study Program, IKIP Siliwangi, Cimahi City, Indonesia \\ $\bowtie$ arf432@gmail.com
}

\begin{abstract}
The success in the modern era is determined by how students strive to have certain skills. This can be achieved by students through the development of cognitive domain, because it is considered as the ability to master subject matter with regard to thinking ability in addition to learning. Hence, this research aims at improving the learning outcomes in the cognitive domain of students at the primary school level. This research was conducted using the Pre-Experiment method with the pretest-posttest One-Group design. The lessons were implemented using Science, Technology, Engineering, and Mathematics (STEM)-based learning, while the learning method was referred to the Engineering Design Process. The stages consist of problem scoping, idea generation, design and construct, design evaluation and re-design. The research involved 30 fourth grade primary school students in Cimahi City as the research samples. The data were collected using observation and analyzed using quantitative descriptive analysis. The research results revealed that there were differences in learning outcomes in the cognitive domain. To conclude, STEM-based learning could improve primary school students' cognitive skills.
\end{abstract}

Keywords: cognitive skills, learning, primary school, STEM, thinking ability

How to Cite: Firdaus, A. R., \& Rahayu, G. D. (2019). Effect of STEM-based Learning on the Cognitive Skills Improvement. Mimbar Sekolah Dasar, 6(2), 198-207. doi:10.17509/mimbar-sd.v6i2.17562

INTRODUCTION The 21 st century principle raises new challenges in the world of education, One of the interesting concerns is the need for a variety of skills related to adapting to society. Based on the results of the education process, students are required to have abilities such as life skills, workforce skills, application skills, personal skills, interpersonal skills and noncognitive skills (Saavedra et al., 2012). These skills have been around for decades, but lately, there has been more encouragement to teach students to have these abilities at every stage of education, because the success in this modern era requires these $21^{\text {st }}$ century skills (Bybee \&
Fuchs, 2006; Rotherham \& Willingham, 2009; Silva, 2009).

The required skills could not be directly possessed by students. Interests, talents, and opportunities to develop these skills also determine the presence or absence of these skills in students. The learning process in school can determine the students' opportunities to develop the required skills, but the magnitude of the development of these skills depends on whether the quality of education in the school is good or not. A quality STEM education should be able to provide wider opportunities for students to develop their competencies in which it is not only Science, but also Technology, Engineering 
Anugrah Ramadhan Firdaus \& Galih Dani Septiyan Rahayu, Effect of STEM based Learning...

Mathematics, and its related areas (Osman \& Saat, 2014).

The quality of education in Indonesia was poor in the world. In 2015, Indonesia was ranked $62^{\text {nd }}$ out of 72 countries, which was still in the top 10 of the lowest ranking, with an average score of 395. Despite being in the low rank, in 2012 and 2015 science performance in 15-year students rose 21 points. Therefore, Indonesia was ranked $5^{\text {th }}$ out of 72 other countries in the acceleration of education. The rapid pace of innovation can produce more students capable of working in the field of science (KEMENDIKBUD, 2016).

The survey conducted by the Trends in Mathematics and Science Study (TIMSS) in 2015 found that Indonesian students were ranked $44^{\text {th }}$ out of 47 countries in terms of natural science achievements. The results of the 2015 TIMSS survey found that $90 \%$ of Indonesian students were only able to master the cognitive domains at level $\mathrm{Cl}$ and C2 for science and mathematics subjects. Level $\mathrm{Cl}$ is related to the knowledge category. This category involves types of knowledge, such as terminology, specific facts, conventions, trends and sequences, classifications and categories, criteria, methodologies, principles and generalizations, theories and structures. Meanwhile, the level C2 is related to the understanding category, which comprises translation, interpretation, and extrapolation (Tikhonova \& Kudinova, 2017).
The data shows the ability of students in Indonesia was limited to only understanding the lesson. This is indicated by the habits of Indonesian students who only memorize during the learning process without the implementation of the concepts learned. Whereas in the future, the challenges for education graduates in Indonesia will be more complex. Based on this phenomenon, it is not surprising that the quality of science learning is still low, so that the students' learning outcomes are not optimal (Firdaus, 2015).

Individuals educated with STEM-based learning are expected to have hard skills that are balanced with soft skills, because the learning process is carried out by active learning methods that include communication, collaboration, problemsolving, leadership, creativity, and others. Hence, STEM education pattern is considered more interesting to be learned (Sanders, 2009), because of the awareness of the important role of technology and engineering in the 21 st century has been believed to improve students' soft skills and hard skills.

Based on the aforementioned elaboration, the proposed research questionnaire: (1) How is the planning of learning based on Science, Technology, Engineering and Mathematics? 2) What is the implementation of learning based on Science, Technology, Engineering, and Mathematics?; and 3) How do the students improve the cognitive abilities after implementing science learning 
based on Science, Technology, Engineering, and Mathematics?

Therefore, this research aims at 1) seeking learning plans based on Science, Technology, Engineering, and Mathematics principle; 2) seeking the implementation of learning based on Science, Technology, Engineering, and Mathematics principle; 3) seeking the improvement of students' cognitive abilities after implementing science learning based on Science, Technology, Engineering, and Mathematics principle.

\section{Science, Technology, Engineering, and Mathematics based learning}

STEM is an acronym for Science, Technology, Engineering, and Mathematics. This acronym was introduced by the United States National Science Foundation in the 1990s as the theme of the education reform movement in this four disciplines to grow the STEM field workforce, to develop STEM-literate citizens, and to increase the global competitiveness of the United States in scientific and technological innovation (Hanover, 2011). STEM education is a "meta-discipline". In other words, it is the creation of a integration-based discipline of other disciplinary knowledge into a new 'whole' rather than in bits and pieces; and an interdisciplinary approach (Morrison, 2006; Tsupros, Kohler, \& Hallinen, 2009).

The STEM approach is used to advance education, in hope that students will be ready to study the fields of science, technology, engineering and mathematics in higher education and can find future work in the STEM field (Figliano, Wells, Mark Sanders, Wilkins, \& Fred Figliano, 2007).

STEM has an effective way to engage students in high-level thinking, and improve problem-solving skills by placing science and mathematics in the context of technology and engineering. The aim of STEM-based learning is to develop school graduates' skills on science, technology, engineering, and mathematics. The essence of STEM education is to prepare the 21 st century workforce with STEM education and its related activities, so that the students can take lessons in classroom/laboratory to be implemented in real life. The development of STEMbased learning must be encouraged and continued to train effective classroom management, thus they can update their knowledge in the modern trends of teaching STEM education. and apply their knowledge to effective student teaching (Ejiwale, 2013).

According to English \& King (2015), STEMbased learning is carried out using stages of the Engineering Design Process consisting of:

1. Problem Scoping (Understanding the boundaries of problem)

Students will clarify and redefine the objectives of the problem, identify possible the emergence of obstacles, explore issues, add context, experiment 
Anugrah Ramadhan Firdaus \& Galih Dani Septiyan Rahayu, Effect of STEM based Learning...

with materials, and build collaborative group work.

2. Idea Generation (Brainstorming and Planning)

Students will share ideas, and formulate them, discuss strategies that will be pursued, and develop a plan.

3. Design and Construct (Model Development)

Students will create a design and then interpret the results of the design. After that students will change design into a model.

4. Design Evaluation (Meeting Constraint) Students will examine the model, then check if there are obstacles, assess and measure the achievement of goals

5. Redesign Model

Students will conduct a review of the first design, create a new design sketch and revise the model.

First, at the stage of problem scoping, students will consider solving possible problems, clarify the objectives of the problems, identify possible obstacles, experiment in finding relevant information and start to build collaboration between groups. Second, at the stage of idea generation, students will brainstorm and make plans. They will share and formulate ideas, discuss strategies and develop plans collaboratively. Third, at the stage of design and construct, students will create a design, interpret the design, and start making models based on the design. Fourth, at the stage of design evaluation, students will examine the model, check the existing obstacles, and make an assessment based on the desired initial goals. Fifth, at the stage of redesign, students will do a review from the beginning, then make a new design and transform it into a new model.

\section{Cognitive}

Cognitive is related to or involves cognition. Cognition is an activity or process to acquire knowledge, or an effort to recognize something through his own experience. Cognitive ability is a person's ability to process one or more information, where the process also involves understanding the obtained information. Cognitive learning outcomes are not single abilities but have several levels. Cognitive classification is widely used in the world of education, and the classification proposed by Bloom (1956) is still widely used.

The ability referred to in this research is the ability in the cognitive domain based on Bloom's taxonomy, which is mastery of subject matter related to thinking ability after learning. The cognitive domain is that involves more aspects of mental or brain. In the cognitive domain, there are six levels of thought processes, ranging from the lowest to the highest level. These levels is abbreviated as " $\mathrm{C}$ " taken from the word "Cognitive". The cognitive abilities of students in this research were only examined from four levels of the cognitive domain: $\mathrm{Cl}$ (remembering), $\quad$ 22 
(understanding), C3 (applying) and C4 (analyzing).

\section{METHOD}

This research is a quantitative research. It employs a pre-experimental method with one-group pretest-posttest research design. According to Rahayu \& Nugraha (2018), the design of one-group pretestposttest research is a study using minimal controls. The design is presented in Figure 1.

\begin{tabular}{c|c|c|c} 
Pre-Test & & Treatment & Post-Test \\
\hline $\mathrm{T}_{1}$ & & $\mathrm{X}$ & $\mathrm{T}_{2}$ \\
\hline & & &
\end{tabular}

Figure 1. Research Design one group pretest-posttest

Based on Rahayu and Nugraha's (2018) steps of one group pretest-posttest design are as follows, this research conducted the following steps:

1. Performing the initial test (TI) to measure the average score obtained by students before being given treatment.

2. Giving treatment $(X)$, where in this research, where the STEM-based learning model was implemented.

3. Conducting the final test (T2) to measure the average score obtained after being given treatment, namely the STEM-based learning model in this research.

4. Comparing $\mathrm{Tl}$ with $\mathrm{T} 2$ to see whether there is a difference in the increase in cognitive learning outcomes.
5. Conducting appropriate statistical tests to see significant differences.

6. Providing interpretation of the research results.

The subjects of this research were fourthgrade students in one of primary schools in Cimahi City. The sampling technique used was non-random sampling, which meant that the research subjects are based on the composition of the members available, feasible, and related to the goals and characteristics of this research.

The procedure of research consisted of four stages, namely the stages of planning, implementation, completion, and publication of the research results. At the planning stage, the activity consisted of analyzing the results of previous studies on STEM-based learning, analyzing the development of teaching materials of science in primary school, compiling instruments, validating instrument, and testing instruments. At the implementation stage, the activities carried out were the conducting pretest, giving the treatment by carrying out learning using the STEM model, and conducting posttest. At the completion stage, the activities carried out were collecting data, processing and analyzing the research results, and preparing research reports. At the publication stage, the activity was publishing the research results.

The instrument used to answer the research questions was multiple-choice written test consisting of 20 questions. 
Anugrah Ramadhan Firdaus \& Galih Dani Septiyan Rahayu, Effect of STEM based Learning...

Before this instrument was used at the pretest and posttest stages, the instrument was examined by the expert and the students, so that the validity, reliability, distinguishing power, and level of difficulty of this instrument were in a good category.

\section{RESULTS}

The research results are in accordance with the formulation of the first lesson about the planning of STEM-based learning by carefully preparing the packaging of learning activities and media used in learning, because STEMbased learning must be able to create a harmonious, dynamic, interesting and challenging class. In addition to creating the classroom atmosphere, STEM-based learning is also expected to create independent students technology-literate, and have high curiosity and good innovations.

Furthermore, the aspects that must be considered in the preparation of STEMbased learning implementation plan are as follows:

1. Understanding the steps of STEM-based learning

2. Developing STEM-based learning steps into learning activities. As implemented in this research: at the stages of scoping problem, the teachers planned learning activities that could stimulate the students to consider solving possible problems, At the stage of idea generation, the teachers prepared learning activities that could stimulate the students to brainstorm and make a plan, so that the students would share and formulate ideas, discuss strategies, and develop plans collaboratively, At the stage of design, the teachers prepared a design, so that the students would create a design, interpret the design and start making models based on the design. At the stage of design evaluation and redesign, since it was carried out by primary school students, so that if there was an inappropriate design, the teachers must be able to explain, remind, and direct the students, so that they were be able to create an appropriate design.

3. Preparing the students' worksheets (LKS - Lembar Kerja Siswa) and technologybased learning media. Hence, it can create a learning atmosphere in accordance with the objectives of STEM-based learning.

The research results were in accordance with the formulation of the problem about the implementation of STEM-based learning, namely the four steps of STEMbased learning consisted of the problem scoping, idea generation, design and construct, design evaluation and redesign. In this research, the learning activities were carried out in three meetings. At the first meeting, the pretest activities was conducted to see students' initial abilities. At the second meeting, the learning activities were carried out in accordance with the steps of the STEM-based learning 
model. There was a finding in this meeting in which the students carried out STEMbased learning quite well, but there were some students who felt they were not used to it, so that they needed encouragement from the teacher. The implementation of learning was brief, namely at the stage of problem scoping, the students considered solving possible problems. In addition, at this stage, the students made a list of solutions to problems, and chose solutions that were able to solve problems, At the idea generation stage, the students brainstormed and made a plan. They shared information in a group with other students to formulate ideas, discuss strategies and develop collaborative plans. At the design and construct stage, the students created a design based on the collaborative formulation and plan, interpreted the design, and started modeling based on the design, At the stage of design evaluation and redesign: the students evaluated their design, and improved the design based on the results of the evaluation.

At the third meeting, post-test were conducted. The stages of learning were certainly directed by the teacher, because the subjects in the research were the fourth-grade students in primary school.

The cognitive ability score data in this research was analyzed using a different test on the average pretest and posttest scores. The difference test on the average score of cognitive abilities was conducted to show whether there were differences in scores from pretest to posttest.

Table 1. Recapitulation of Science Cognitive Ability Test Results

\begin{tabular}{lll}
\hline Data & Pretest & Posttest \\
\hline $\mathrm{N}$ & 30 & 30 \\
Average & 7.4 & 16.3 \\
\hline N-gain & 0.72 & \\
\hline
\end{tabular}

Table 1 shows that the average score of cognitive abilities of students at the pretest score was 7.4, and at the posttest was 16.3. The increase calculated based on $n$ gain results in a $n$-gain score was 0.72 . This indicated that there was an increase in scores with high categories.

\section{DISCUSSION}

Based on the cognitive ability score test analysis, the results revealed that there was a significant increase in cognitive abilities from pretest to posttest. It indicated that the students were actively involved in the learning process, in meaning that they were actively thinking and carrying out in the learning activities, so that learning became more meaningful. This increase was influenced by the learning process that used STEMbased LKS. These results were in line with the research conducted by Barret, Moran, \& Woods (2014), which showed that STEM integrated module material successfully promotes the students' learning, as indicated by a significant increase in the average score at the time of assessment. 
The students' experiences in finding solutions during the engineering design process gave them the opportunity to conduct trial and error. Although the students had failed several times to implement the best students' solution, it actually contributed to the development of knowledge. This process made a meaningful learning, and supported the improvement of the students' learning outcomes.

According to English \& King (2015), the implementation of the engineering design is considered as the successful method in developing STEM-learning material, and it also became the reinforcement in solving STEM-based problems. The STEM-based learning material implemented in this research immensely focused on the engineering design process, and involved the students in this process of the STEM challenge, from clearly identifying problems to creating and developing solutions. The previous research showed that engineering design was an effective approach to support science learning (Schnittka \& Bell, 2011).

The stage of idea generation in the engineering design encouraged the students to recall the knowledge that had been learned. This encouraged students to connect the concepts that had been learned to be implemented in engineering design activities. The learning results integrated into several disciplines showed that the students could be good problem solvers, which are indicated from positive responses, and the improvement of their learning outcomes (Stinson et al., 2009). The previous research showed that STEM had a positive effect on the students' learning outcomes, and helped students understand science better when integrated with real problems, which became the key aspects of science competence (Hurley, 2001).

Based on the observations results after learning, differences in the increase in cognitive abilities of the students based on the superior and moderate rates were occurred because high students were more interested in making observations and experiments, so that they paid attention, and observed the steps of the results of the experiment correctly. In contrast with this group, they actually did not look serious in the experiments, and instead chose to directly fill in the LKS. This was in line with Akhtar (2006) who affirmed that in attempting to provide a more concrete and realistic learning experience to the students, the teachers must use and prepare special teaching materials. The existence of LKS supported this learning process in helping the students develop their understanding. The advantages of STEM in giving students the opportunity to obtain hands-on experiences can help students gain meaningful learning, and help students improve their cognitive abilities. Therefore, as a renewal in teaching, STEM can provide alternative learning solutions to face the 21 st century. 


\section{CONCLUSION}

Based on the research results and findings, STEM-based learning had an influence on the improvement of the primary school students' cognitive abilities. The improvement of cognitive abilities was proven by a high n-gain score resulting from the achievement of the pretest score to the posttest score. This showed that the students' cognitive abilities increased after carrying out STEM-based learning. Moreover, the research using STEM-based learning required a careful planning. In addition to preparing learning planning, the teaching material must also be well prepared, so that students were motivated and in accordance with student characteristics and the teaching materials. A high level of creativity is needed in implementing the direct learning to respond to the students' responses that are beyond predictions, such as dividing groups of students in the control class.

\section{RECOMMENDATION}

Based on the conclusion of this research, there are several recommendations for the further researchers who will conduct the research regarding STEM-based learning and cognitive abilities. First, it is suggested ti add more samples in order to obtain the generalized research results that will be broader in scope. Second, it is suggested to developf STEM-based learning with various teaching materials, for instance, in forms of ICT-based teaching materials or other teaching materials to facilitate primary school students in learning activities. Third, it is suggested that the findings of this research results are developed in order to implement STEMbased learning to be more useful in primary schools, both in developing cognitive, affective, and psychomotor abilities of $p$ school primary students.

\section{ACKNOWLEDGMENTS}

Gratitude is extended to Directorate General of Research and Development Reinforcement of Ministry of Research, Technology and Higher Education who has provided the research funding through a research program for beginner lecturers, so that this research could be conducted properly in accordance with the targets and objectives.

\section{REFERENCES}

Barrett, B. S., Moran, A. L., \& Woods, J. E. (2014). Meteorology meets engineering: an interdisciplinary STEM module for middle and early secondary school students. International Journal of STEM Education, $\quad 1(1)$, 1-7. https://doi.org/10.1 186/2196-7822-1-6

Bloom, B. S. (1956). Taxonomy of Educational Objectices Book 1: Cognitive Domain. Longman: London.

Bybee, R. W., \& Fuchs, B. (2006). Preparing the 21st century workforce: A new reform in science and technology education. Journal of Research in Science Teaching, 43(4), 349-352. https://doi.org/10.1002/tea.20147

Ejiwale, J. A. (2013). Barriers to Successful Implementation of PDM. Journal of Education and Learning, 7(2), 63-74. https://doi.org/10.1007/978-3-31924436-5_20

English, L. D., \& King, D. T. (2015). STEM 
learning through engineering design: fourth-grade students' investigations in aerospace. International Journal of STEM Education, 2(1). https://doi.org/10.1186/s40594-0150027-7

Figliano, F., Wells, J. G., Mark Sanders, C. E., Wilkins, J. L., \& Fred Figliano, B. (2007). Strategies For Integrating STEM Content: A Pilot Case Study.

Firdaus, A. R. (2015). Penerapan Metode Eksperimen untuk Meningkatkan Hasil Belajar Siswa pada Materi Energi. 6th Pedagogy International Seminar 2015. 1-412. Retrieved from http://jurnal.upi.edu/proceedingpgsd /view/3699/penerapan-metodeeksperimen-untuk-meningkatkanhasil-belajar-siswa-pada-materienergi.html

Hanover. (2011). K-12 STEM Education Overview.

Hurley, M. M. (2001). Reviewing Integrated Science and Mathematics: The Search for Evidence and Definitions From New Perspectives. School Science and Mathematics, 101(5), 259-268.

https://doi.org/10.1111/j.1949-

8594.2001.tb18028.x

KEMENDIKBUD. (2016). Peringkat dan Capaian PISA Indonesia Mengalami Peningkatan. Retrieved from https://www.kemdikbud.go.id/main/ blog/2016/12/peringkat-dancapaian-pisa-indonesia-mengalamipeningkatan

Morrison, J. S. (2006). Attributes of STEM education: the students, the academy, the classroom. TIES STEM barrEducation Monograph Series. https://doi.org/10.1016/j.anl.2012.01.0 11

Osman, K., \& Saat, R. M. (2014). Editorial. Science technology, engineering and mathematics (STEM) education in Malaysia. Eurasia Journal of Mathematics, Science and Technology Education, 10(3), 153154.

https://doi.org/10.12973/eurasia.2014. $1077 a$

Rahayu, G. D. S., \& Nugraha, F. F. (2018).
Effect of Cooperative Learning Model Type Team Game Tournament (TGT) on Cross-Cultural Skills in Learning Science Social Knowledge in Primary School. Journal of Elementary Education, 2(1), 63-70.

Rotherham, A. J., \& Willingham, D. (2009). 21 st Century Skills: The Challenges Ahead. Educational Leadership, 67(1), 16-21. Retrieved from http://www.ascd.org/publications/ed ucationalleadership/sept09/vol67/num01/21stCentury-Skills@-The-ChallengesAhead.aspx

Saavedra, A. R., Corporation, T. R., Opfer, V. D., Corporation, T. R., Jackson, T., Kehayes, J., ... Perkins, D. (2012). 21. Century Skills. (April), 1-35.

Sanders, B. M. (2009). STEMmania. 20-27.

Schnittka, C., \& Bell, R. (2011). Engineering design and conceptual change in science: Addressing thermal energy and heat transfer in eighth grade. International Journal of Science Education, 33(13), 1861-1887. https://doi.org/10.1080/09500693.2010 .529177

Silva, E. (2009). Measuring Skills for 21stCentury Learning. PHI DELTA KAPPAN, 90(9), 630-634. https://doi.org/https://doi.org/10.1177 /003172170909000905

Tikhonova, E., \& Kudinova, N. (2017). Sophisticated Thinking: Lower Order Thinking Skills. 2nd International Multidisciplinary Scientific Conference on Social Sciences and Arts SGEM2015, 2(August). https://doi.org/10.5593/sgemsocial20 15/b12/s3.117

Tsupros, N., Kohler, R., \& Hallinen, J. (2009). STEM Education in Southwestern Pennsylvania the missing components. Retrieved from https://www.cmu.edu/gelfand/docu ments/stem-survey-report-cmuiul.pdf 